(c) American Dairy Science Association, 2007.

\title{
Dietary Energy Source in Dairy Cows in Early Lactation: Metabolites and Metabolic Hormones
}

\author{
A. T. M. van Knegsel, ${ }^{\dagger} \dagger^{1}$ H. van den Brand, ${ }^{\star}$ E. A. M. Graat,‡ J. Dijkstra,† R. Jorritsma,\# \\ E. Decuypere,§ S. Tamminga,† and B. Kemp* \\ *Adaptation Physiology Group, \\ †Animal Nutrition Group, and \\ ¥Quantitative Veterinary Epidemiology Group, Wageningen Institute of Animal Sciences, Wageningen University, \\ $\mathrm{PO}$ Box 338, $6700 \mathrm{AH}$ Wageningen, the Netherlands \\ \#Utrecht University, PO Box 80151, 3508 TD Utrecht, the Netherlands \\ §Catholic University Leuven, Kasteelpark Arenberg 30, 3001 Heverlee, Belgium
}

\section{ABSTRACT}

Negative energy balance-related metabolic disorders suggest that the balance between available lipogenic and glucogenic nutrients is important. The objectives of this study were to compare the effects of a glucogenic or a lipogenic diet on liver triacylglycerides (TAG), metabolites, and metabolic hormones in dairy cows in early lactation and to relate metabolite concentrations to the determined energy retention in body mass (ER). Sixteen dairy cows were fed either a lipogenic or glucogenic diet from wk 3 prepartum to wk 9 postpartum (pp) and were housed in climate respiration chambers from wk 2 to 9 pp. Diets were isocaloric (net energy basis). Postpartum, cows fed a lipogenic diet tended to have higher nonesterified fatty acid concentration (NEFA; $0.46 \pm$ 0.04 vs. $0.37 \pm 0.04 \mathrm{mmol} / \mathrm{L}$ ) and lower insulin concentration $(4.0 \pm 0.5$ vs. $5.5 \pm 0.6 \mu \mathrm{IU} / \mathrm{mL})$. No difference was found in plasma glucose, $\beta$-hydroxybutyrate, insulin-like growth factor-I, and thyroid hormones. Liver TAG was equal between both diets in wk -2 and $2 \mathrm{pp}$. In wk $4 \mathrm{pp}$ cows fed the glucogenic diet had numerically lower TAG levels, although there was no significant dietary effect. Negative relationships were detected between ER and milk fat and between ER and NEFA. A positive relationship was detected between ER and insulin concentration. Overall, results suggest that insulin plays a regulating role in altering energy partitioning between milk and body tissue. Feeding lactating dairy cows a glucogenic diet decreased mobilization of body fat compared with a lipogenic diet. The relative abundance of lipogenic nutrients, when feeding a more lipogenic diet, is related to more secretion of lipogenic nutrients in milk, lower plasma insulin, and higher plasma NEFA concentration.

Received July 28, 2006

Accepted November 7, 2006

${ }^{1}$ Corresponding author: Ariette.vanKnegsel@wur.nl
Key words: negative energy balance, lipogenic nutrient, glucogenic nutrient

\section{INTRODUCTION}

The negative energy balance (NEB) in early lactation is associated with metabolic disorders such as fatty liver, ketosis (Grummer, 1993), and ruminal acidosis (Owens et al., 1998). Metabolites and metabolic hormones are recognized as signals in the interaction between NEB and metabolic disorders in dairy cows.

In an earlier published review (van Knegsel et al., 2005) it was hypothesized that part of the metabolic effect of NEB is an imbalance in $\mathrm{C} 2$ :C3 nutrient ratio. The C2 and C3 nutrients can split up into fragments containing 2 or $3 \mathrm{C}$ atoms; $\mathrm{C} 2$ and $\mathrm{C} 3$ nutrients are directly supplied in the diet or are derived from larger compounds. This imbalance in $\mathrm{C} 2: \mathrm{C} 3$ nutrient ratio is induced by an excess of $\mathrm{C} 2$ nutrients (stimulated by body fat mobilization) that cannot be oxidized completely as a result of a deficiency in $\mathrm{C} 3$ nutrients. There are 3 major alternative pathways for $\mathrm{C} 2$ nutrients. First, an increase in incomplete oxidation of $\mathrm{C} 2$ nutrients may occur, which causes an increase in plasma ketone body concentration, ultimately resulting in ketosis. Second, C2 nutrients can be esterified and stored in the liver as triacylglycerides (TAG), potentially causing a fatty liver. Third, C2 nutrients can be transported to the mammary gland and transformed into milk fat (Palmquist and Mattos, 1978), resulting in increased milk fat production.

It has been suggested (Drackley, 1999; van Knegsel et al., 2005) that diets high in lipogenic nutrient content increase the severity and risk of ketosis and fatty liver by increasing the $\mathrm{C} 2$ :C3 nutrient ratio. In dairy cows, lipogenic dietary ingredients such as dietary fat, or forages that stimulate the ruminal production of acetate and butyrate, are expected to increase the availability of $\mathrm{C} 2$ nutrients. In contrast, glucogenic dietary ingredients are either fermented in the rumen to produce high 
amounts of propionate or are digested in the small intestine and absorbed as glucose. Additionally, high-producing dairy cows experience NEB in early lactation. Negative energy status promotes mobilization of body fat (Tamminga et al., 1997) and increases the availability of $\mathrm{C} 2$ compounds.

The importance of an appropriate balance of lipogenic and glucogenic nutrients to optimize milk production efficiency and to decrease metabolic disorders has been addressed previously (Adler, 1970; Kronfeld, 1976; Drackley, 1999). However, studies that test this hypothesis by feeding isocaloric diets differing in lipogenic and glucogenic nutrients are scarce. The companion paper showed that dietary energy source alters energy partitioning in dairy cows in early lactation (van Knegsel et al., 2007). Although energy intake was not different between diets, cows fed a mainly lipogenic diet had higher milk fat and milk energy outputs and an increased body fat mobilization compared with cows fed a glucogenic diet. To obtain insight into the metabolic signals of this observed shift in energy partitioning, the objective of this study was to measure the effects of feeding a lipogenic or a glucogenic diet on liver TAG content, metabolites and metabolic hormones. Various studies have dealt with relationships among plasma NEFA, ketone bodies, glucose, insulin, or milk fat and milk protein and the energy balance $(\mathbf{E B})$ in dairy cattle (De Vries and Veerkamp, 2000; Kokkonen et al., 2005). Such relationships were based on the estimated EB, calculated from energy intake and milk production. To our knowledge, the measured EB has not been used in testing associations with metabolite and metabolic hormone concentrations in dairy cows in early lactation. Therefore, the second objective of this study was to relate blood metabolites, metabolic hormones, and milk characteristics to the measured EB in early lactation dairy cattle.

\section{MATERIALS AND METHODS}

\section{Animals, Management, and Experimental Design}

The experiment was conducted at Wageningen University and Research Centre (the Netherlands). The Institutional Animal Care and Use Committee of Wageningen University approved the experimental protocol. Sixteen Holstein-Friesian dairy cows, with comparable milk production $(>9,500 \mathrm{~kg}$ of fat- and proteincorrected milk in $305 \mathrm{~d}$ ), were selected from a group of 44 cows that were inseminated at synchronized ovulation (the Crestar+ method, Intervet, Boxmeer, the Netherlands). Ovulation was synchronized to obtain 4 groups of 4 natural calving cows with a maximum of $4 \mathrm{~d}$ variation in calving date. Selection was based on calving date. Within each group, cows were assigned to either the glucogenic or lipogenic diet 3 wk prepartum. Parity of the selected cows ranged from 2 to 4 . Within $1 \mathrm{wk}$ postpartum (pp), 4 cows were transported and housed, paired by diet, in 2 identical, large, open-circuit, indirect climate respiration chambers (Verstegen et al., 1987) for 8 wk to determine energy retention in body mass (ER) as reported in the companion paper (van Knegsel et al., 2007). Per group dietary treatment was assigned alternatively to 1 of the 2 chambers. In the climate respiration chamber, the cows were housed in a tie stall. Cows were exposed to $16 \mathrm{~h}$ of light and $8 \mathrm{~h}$ of darkness. Cows were milked twice daily (0600 and $1700 \mathrm{~h}$ ) in the chamber using a mobile milking system.

\section{Feeding}

The complete ingredient and chemical composition of both diets are described in the companion paper (van Knegsel et al., 2007). In summary, diets were fed as TMR and formulated to be isocaloric (NE basis) and equal in intestinal digestible protein and degraded protein balance (Dutch DVE/OEB system; Tamminga et al., 1994). Postpartum, the concentrate supply increased stepwise by $0.5 \mathrm{~kg} / \mathrm{d}$ until concentrate intake reached $10.0 \mathrm{~kg} / \mathrm{d}$ with a concentrate to forage ratio of 40:60 (DM basis). Forage consisted of grass silage, corn silage, and chopped alfalfa hay in a ratio of 45:45:10 (DM basis). Diets were fed twice daily in equal proportions before milking.

\section{Sampling Procedures}

Liver biopsies were taken in wk $-2,2$, and 4 relative to calving. Before the biopsy, the biopsy site was clipped and disinfected. A stab incision was made at the location of the greater trochanter in the 11th intercostal space on the right side of the cow. The biopsy was obtained under local anesthesia $(7 \mathrm{~mL}$ of lidocaine- $\mathrm{HCl}$ $2 \%$ with adrenaline, Alfasan Nederland B.V., Woerden, the Netherlands) with a $17 \mathrm{G} \times 200 \mathrm{~mm}$ biopsy needle. Approximately $300 \mathrm{mg}$ of wet weight of liver tissue was harvested by moving the biopsy needle several times in the direction of the contralateral ulna. Tissue was kept for up to $24 \mathrm{~h}$ on ice in a $0.9 \% \mathrm{NaCl}$ solution. Subsequently, connective tissue was removed, and the sample was weighed and stored at $-20^{\circ} \mathrm{C}$ until analysis.

Samples of jugular blood were obtained weekly from wk -2 to 9 pp at $3 \mathrm{~h}$ after the a.m. feeding and immediately before liver biopsy if both were on the same day. Blood was collected in evacuated tubes (Vacuette, Greiner BioOne, Kremsmünster, Austria) containing either $\mathrm{NaF}$ for glucose determination, Li-heparin for NEFA, BHBA, cholesterol, urea, triiodothyronine (T3), and thyroxin (T4) determination, or EDTA for IGF- 
I and insulin determination. Plasma was obtained by centrifugation, aliquoted, and frozen at $-20^{\circ} \mathrm{C}$ until analysis.

\section{Analytical Procedures}

Blood and liver samples were analyzed in a quality controlled veterinary laboratory (Stichting Kwaliteitsbewaking Medische Laboratoriumtechniek, Nijmegen, the Netherlands). Analyses for glucose, NEFA, BHBA, and cholesterol were performed using commercially available kits (glucose: reagent 443355 for Synchron CX7 analyzer, Beckman Instruments B.V., Mijdrecht, the Netherlands, Rukkwamsuk et al., 1999; NEFA: FA 115 kit, Randox Laboratories Ltd., Crumlin, UK, Rukkwamsuk et al., 1999; BHBA: Ranbut kit, Randox, Rukkwamsuk et al., 1998; cholesterol: cholesterol reagens for Synchron CX5, Beckman Instruments B.V.; Bouchard et al., 2002). Insulin concentration was determined using an RIA kit (Coat-a-Count Insulin, Diagnostic Products Corporation, Los Angeles, CA; Rukkwamsuk et al., 1999). Triiodothyronine, T4, and IGF-I were analyzed as described by Gerrits et al. (1998). Liver tissue was handled as described by Van den Top et al. (1995) and analyzed on a Synchron CX5 analyzer with a TAG reagent (Beckman Instruments B.V.). The accuracy of each assay was monitored with the use of a commercial reference serum sample (Bovine precision serum, Randox) and the outcome deviated $<5 \%$ from the target values.

\section{Statistical Analyses}

Three cows were excluded from the experiment because of left displaced abomasums: in group 2, 1 cow fed the lipogenic diet; and in group 3, 2 cows fed the glucogenic diet. Therefore, values are based on 13 cows (glucogenic diet: $\mathrm{n}=6$; lipogenic diet: $\mathrm{n}=7$ ) for analysis of metabolites and metabolic hormones (model 1) or 6 climate respiration chambers $(\mathrm{n}=3$ per dietary treatment per lactation week) for analysis of relationships between ER and metabolites, metabolic hormones, milk fat, and fat to protein ratio (model 2). Although multiple measurements per animal cannot be regarded as independent units of observation, repeated-measures ANOVA (PROC MIXED of SAS, version 9.1; Littell et al., 2006) was performed. Cow (model 1) or chamber (model 2 ) was included as the repeated subject. First, metabolites and metabolic hormones were analyzed with diet (glucogenic or lipogenic), week ( -2 to $9 \mathrm{pp}$ ), and their interaction included in the model as fixed effects (both as class variables; model 1a). In case of lack of significance $(P>0.05)$, the diet $\times$ week interaction was excluded from the model. Additionally, the same analysis with model 1 was performed for the prepartum and postpartum data separately. Second, to quantify metabolic relationships, plasma BHBA, insulin, liver TAG content, and milk fat were analyzed with NEFA and glucose included as fixed effects in the repeated measurements model 1 (model $1 \mathrm{~b}$ ) to obtain regression coefficients $(\beta)$. Diet was not significant $(P>0.05)$ and therefore not included as a covariable. Third, to test possible indicators for ER, energy retention as body fat $\left(\mathbf{E R}_{\mathbf{f}}\right)$ and energy retention as body protein $\left(\mathbf{E R}_{\mathbf{p}}\right)$ were analyzed with either milk fat, fat to protein ratio, plasma glucose, NEFA, BHBA, insulin, IGF-I, T3, T4, or liver TAG content included as fixed effects in a repeated measurements model (model 2) to obtain regression coefficients $(\beta)$. To avoid collinearity, week was not included in the model. Concerning the 3 mentioned analyses, a first-order autoregressive covariance structure [AR(1)] was the best fit and was used to account for within-cow (model 1a and 1b) or within-chamber variation (model 2). The only exception was liver TAG in which a compound symmetry covariance structure was best. The null model likelihood ratio test (PROC MIXED of SAS, version 9.1; Littell et al., 2006) confirmed that modeling the extra covariance was significant over the null model $(P<0.001)$. Model assumptions were evaluated by examining the distribution of residuals. Transformation (natural logarithm) of plasma insulin concentration was necessary to obtain normal distribution.

\section{RESULTS}

\section{Animal Performance}

The analyses of DMI, ER, milk yield, and milk composition are described in the companion article (van Knegsel et al., 2007). In summary, DMI, gross energy intake (GE), ME, heat production, milk yield (Figure 1), and milk protein (\%) did not differ between diets. Milk fat $(\%)$ and daily milk fat yield were higher $(P<0.05)$ in cows fed the lipogenic diet compared with cows fed the glucogenic diet. Energy retention was numerically lower $(P=0.12)$ for cows fed the lipogenic diet compared with cows fed the glucogenic diet. Moreover, $\mathrm{ER}_{\mathrm{p}}$ did not differ between diets, but $\mathrm{ER}_{\mathrm{f}}$ tended to be lower $(P=0.08)$ for cows fed the lipogenic diet compared with cows fed the glucogenic diet.

\section{Metabolites, Metabolic Hormones, and Liver TAG}

Plasma BHBA, cholesterol, glucose, IGF-I, T3, and $\mathrm{T} 4$ concentrations were not different between diets (Table 1). Plasma BHBA, cholesterol, glucose, and IGF-I concentrations were different $(P<0.01)$ over time (Figure 2). Plasma NEFA concentration tended $(P=0.08)$ 

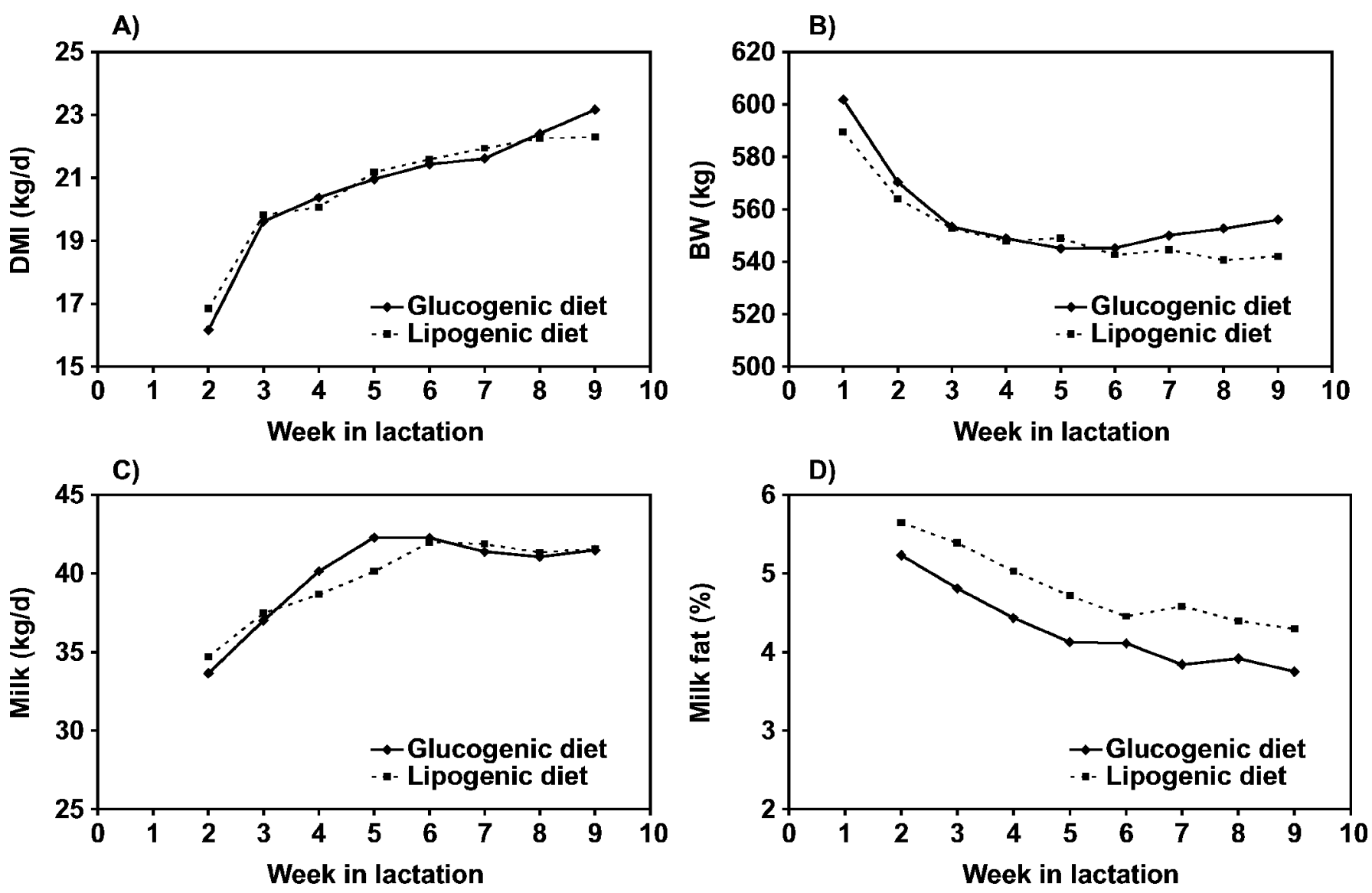

Figure 1. A) DMI (kg/d); B) BW (kg); C) milk yield (kg/d); and D) milk fat (\%) from wk 2 to 9 postpartum for dairy cows fed a mainly glucogenic or lipogenic diet. Values represent least squares means. Overall SEM: DMI $=0.05 ; \mathrm{BW}=11.5 ;$ milk yield $=0.7$; milk fat $=0.05$.

to be lower for cows fed the glucogenic diet compared with cows fed the lipogenic diet. A diet $\times$ week interaction $(P<0.01)$ was detected for plasma NEFA and cholesterol. Plasma NEFA concentration increased earlier (wk 0) and decreased later for cows fed the lipogenic diet compared with cows fed the glucogenic diet. Plasma insulin concentration tended $(P=0.11)$ to be higher for cows fed the glucogenic diet compared with cows fed the lipogenic diet. Postpartum, the plasma insulin concentration was significantly higher $(P<0.05)$ for cows fed the glucogenic diet. Plasma urea was lower $(P<$ 0.01 ) for cows fed the glucogenic diet compared with cows fed the lipogenic diet. Liver TAG content increased from wk 2 prepartum to wk $2 \mathrm{pp}$, but the increase was similar for both diets (Figure 2). From wk 2 to $4 \mathrm{pp}$, liver TAG content decreased again. In wk 4 liver TAG content was numerically lower $(P>0.05)$ for cows fed the glucogenic diet.

\section{Relationships Between Metabolites and Metabolic Hormones}

Plasma NEFA concentration was positively related to liver TAG content $(P<0.01)$ and milk fat percentage
$(P<0.05)$ and negatively related to plasma insulin concentration (Table 2). Plasma glucose was negatively related to plasma BHBA, liver TAG $(P<0.01)$, and milk fat $(P<0.05)$. There was a positive relationship $(P<$ 0.01 ) between plasma glucose and insulin concentration.

\section{Relationships with ER}

Energy retention, determined by indirect calorimetry in the climate respiration chambers, and reported in the companion paper (van Knegsel et al., 2007), was negatively associated $(P<0.01)$ with milk fat $(\%)$ and plasma NEFA concentration (Table 3 ). There was a tendency $(P=0.10)$ for a positive relationship between ER and plasma insulin. No significant relationships $(P$ $>0.05$ ) existed between ER and the milk fat to protein ratio, liver TAG content, plasma glucose, BHBA, IGF$\mathrm{I}, \mathrm{T} 3$, or $\mathrm{T} 4 ; \mathrm{ER}_{\mathrm{f}}$ and $\mathrm{ER}_{\mathrm{p}}$ showed a similar relationship as with overall ER.

\section{DISCUSSION}

The objective of this study was to obtain insight into the metabolic signals of a shift in energy partitioning 
Table 1. Plasma NEFA, BHBA, cholesterol, liver triacylglyceride (TAG), plasma glucose, insulin, IGF-I, triiodothyronine (T3), and thyroxin (T4) and urea from wk -2 to 9 postpartum for dairy cows fed a mainly glucogenic or lipogenic diet ${ }^{1}$

\begin{tabular}{|c|c|c|c|c|c|c|}
\hline \multirow[b]{2}{*}{ Variable } & \multirow[b]{2}{*}{$\operatorname{Diet}^{2}$} & \multirow[b]{2}{*}{ Prepartum } & \multirow[b]{2}{*}{ Postpartum } & \multicolumn{3}{|c|}{$P$-value ${ }^{3}$} \\
\hline & & & & Diet (D) & Week (W) & $\mathrm{D} \times \mathrm{W}^{4}$ \\
\hline \multirow[t]{2}{*}{ NEFA (mmol/L) } & G & $0.20 \pm 0.02$ & $0.37 \pm 0.04$ & 0.08 & $<0.01$ & $<0.01$ \\
\hline & $\mathrm{L}$ & $0.23 \pm 0.02$ & $0.47 \pm 0.04$ & & & \\
\hline \multirow[t]{2}{*}{ BHBA (mmol/L) } & $\mathrm{G}$ & $0.64 \pm 0.04$ & $1.93 \pm 0.20$ & 0.34 & $<0.01$ & NS \\
\hline & $\mathrm{L}$ & $0.70 \pm 0.04$ & $2.20 \pm 0.19$ & & & \\
\hline \multirow[t]{2}{*}{ Cholesterol (mmol/L) } & $\mathrm{G}$ & $2.25 \pm 0.18$ & $4.18 \pm 0.29$ & 0.17 & $<0.01$ & 0.01 \\
\hline & $\mathrm{L}$ & $2.25 \pm 0.17$ & $4.83 \pm 0.27$ & & & \\
\hline \multirow{4}{*}{$\begin{array}{l}\text { Liver TAG } \\
\text { (mg/g of wet weight) } \\
\text { Glucose (mmol/L) }\end{array}$} & $\mathrm{G}$ & $21.4 \pm 1.7$ & $82.1 \pm 16.0$ & 0.46 & $<0.01$ & NS \\
\hline & $\mathrm{L}$ & $18.1 \pm 1.6$ & $107.3 \pm 14.2$ & & & \\
\hline & G & $3.46 \pm 0.10$ & $2.51 \pm 0.12$ & 0.85 & $<0.01$ & NS \\
\hline & $\mathrm{L}$ & $3.48 \pm 0.10$ & $2.55 \pm 0.11$ & & & \\
\hline \multirow[t]{2}{*}{ Insulin ${ }^{5}$} & $\mathrm{G}$ & $1.85 \pm 0.24$ & $1.53^{\mathrm{a}} \pm 0.08$ & 0.11 & $<0.01$ & NS \\
\hline & $\mathrm{L}$ & $1.96 \pm 0.23$ & $1.29^{b} \pm 0.07$ & & & \\
\hline \multirow[t]{2}{*}{ IGF-I (ng/mL) } & $\mathrm{G}$ & $24.79 \pm 3.19$ & $16.63 \pm 0.94$ & 0.25 & $<0.01$ & NS \\
\hline & $\mathrm{L}$ & $32.14 \pm 2.98$ & $16.83 \pm 0.88$ & & & \\
\hline \multirow[t]{2}{*}{$\mathrm{T} 4$ (ng/mL) } & $\mathrm{G}$ & $16.02 \pm 1.07$ & $11.41 \pm 0.50$ & 0.52 & $<0.01$ & NS \\
\hline & $\mathrm{L}$ & $16.44 \pm 1.02$ & $11.75 \pm 0.46$ & & & \\
\hline \multirow[t]{2}{*}{ T3 (ng/mL) } & G & $0.87 \pm 0.09$ & $0.62 \pm 0.04$ & 0.83 & $<0.01$ & NS \\
\hline & $\mathrm{L}$ & $0.86 \pm 0.09$ & $0.63 \pm 0.03$ & & & \\
\hline \multirow[t]{2}{*}{ Urea $(\mathrm{mmol} / \mathrm{L})$} & G & $3.81 \pm 0.12$ & $4.07^{\mathrm{a}} \pm 0.16$ & $<0.01$ & $<0.01$ & NS \\
\hline & $\mathrm{L}$ & $4.10 \pm 0.11$ & $4.87^{\mathrm{b}} \pm 0.15$ & & & \\
\hline
\end{tabular}

\footnotetext{
${ }^{\mathrm{a}, \mathrm{b}}$ Values within a variable and within period (prepartum or postpartum) with different superscripts differ significantly $(P<0.05)$.

${ }^{1}$ Values represent least squares means $( \pm$ SEM) per diet, pooled prepartum or postpartum. Prepartum $=$ wk -2 and -1 ; postpartum $=$ wk $0,1, \ldots 9$.

${ }^{2} \mathrm{G}=$ glucogenic $\operatorname{diet}(\mathrm{n}=6$ cows $) ; \mathrm{L}=$ lipogenic $\operatorname{diet}(\mathrm{n}=7$ cows $)$.

${ }^{3}$ Analyzed with model 1 with wk $=-2,-1, \ldots 9$ included.

${ }^{4}$ Diet $\times$ week interaction was excluded from the model if not significant $(P>0.05)$.

${ }^{5}$ Natural logarithm of plasma insulin concentration $(\mu \mathrm{IU} / \mathrm{mL})$.
}

(van Knegsel et al., 2007) after altering dietary energy source in dairy cows in early lactation. The second objective was to relate metabolites, metabolic hormones, and milk characteristics to the $\mathrm{EB}$, as measured by indirect calorimetry. In the discussion we focus on how the measured metabolic effects of dietary energy source may be related to the effects on energy partitioning of dietary energy source.

It was shown (van Knegsel et al., 2007) that feeding early lactation dairy cows a diet high in lipogenic nutrients resulted in an increase $(P<0.05)$ in milk fat yield. This increase was mainly caused by an increase in daily secretion of C16:0, C18:0, and C18:1 fatty acids. Dietary fat as well as mobilized body fat were higher for cows fed the lipogenic diet; both fat sources likely contributed to this increase in long-chain fatty acids. Furthermore, the contrast in total fat available from both mobilized body fat reserves and dietary fat for maintenance and milk production increased during wk 2 to $4 \mathrm{pp}$. Based on observed dietary fat intake and mobilized body fat and assuming a fat digestibility of 0.86 (NRC, 2001), we estimated that in wk $2 \mathrm{pp}$, cows fed the glucogenic diet had $1.66 \mathrm{~kg}$ of fat available per day for maintenance and milk production. Cows fed the lipogenic diet had
$2.04 \mathrm{~kg}$ of fat available per day in wk $2 \mathrm{pp}$. From wk 2 to $4 \mathrm{pp}$, cows fed the glucogenic diet had a $42 \%$ decrease in fat availability to $0.96 \mathrm{~kg} / \mathrm{d}$ in wk 4 . However, fat availability for cows fed the lipogenic diet decreased much less in this period ( $13 \%$ to $1.79 \mathrm{~kg} / \mathrm{d}$ in wk 4). Thus, differences in fat availability could explain the dietary difference in plasma cholesterol concentration, a tendency for a difference between diets in plasma NEFA concentration, and possibly the numerical difference between diets in liver TAG in wk 4 . However, liver TAG content was not statistically different between diets. The rate of decrease in fat availability was equal for both groups after wk 4 . In addition, body fat mobilization was negative in wk 9 for cows fed the glucogenic diet and the BHBA concentration was lower $(P<0.05)$ compared with cows fed the lipogenic diet.

The difference in mobilized body fat and EB between diets, as reported in the companion article (van Knegsel et al., 2007), may be explained by effects of dietary energy source on plasma insulin concentration. In this study, a trend was found for a higher plasma insulin concentration in cows fed the glucogenic diet compared with cows fed the lipogenic diet. The difference between diets in plasma insulin concentration was significant 
A)

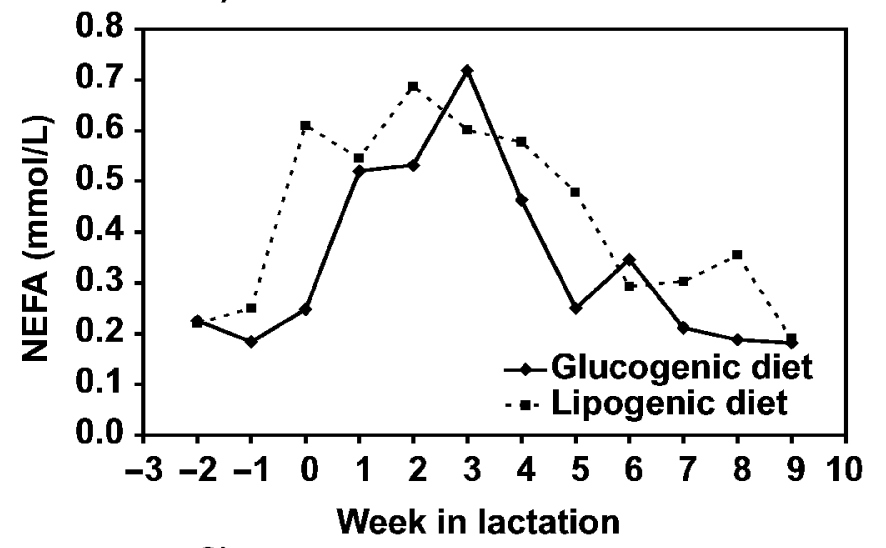

C)

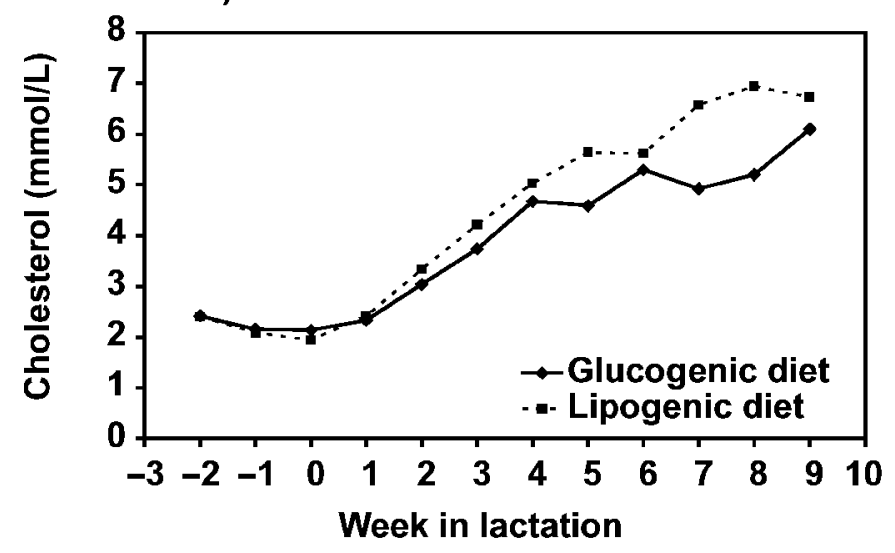

E)

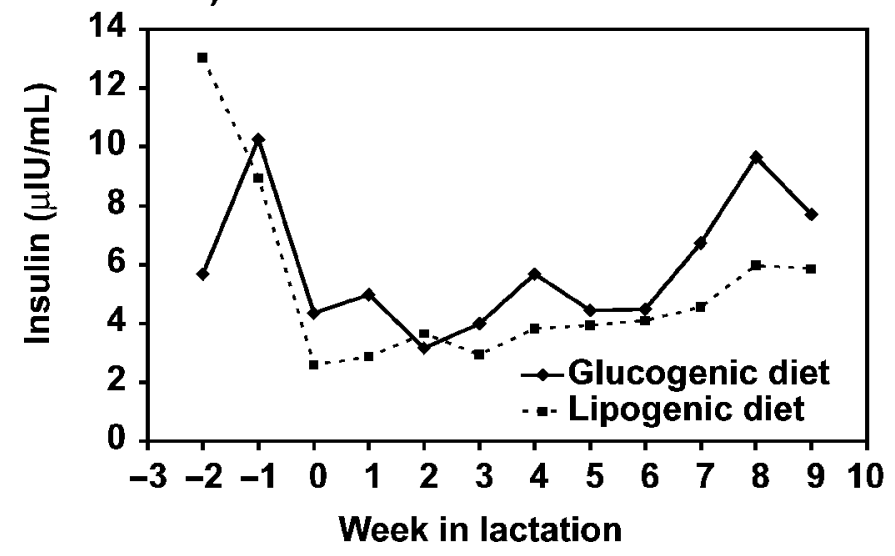

B)

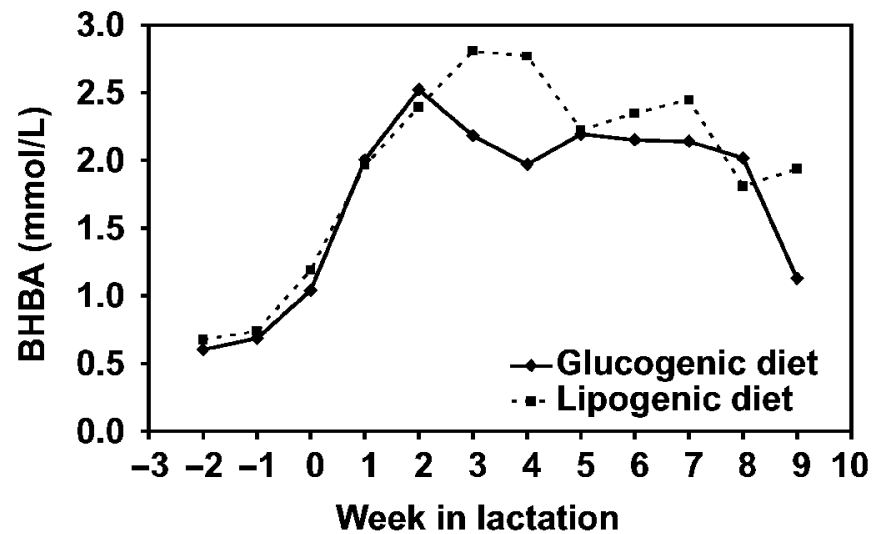

D)

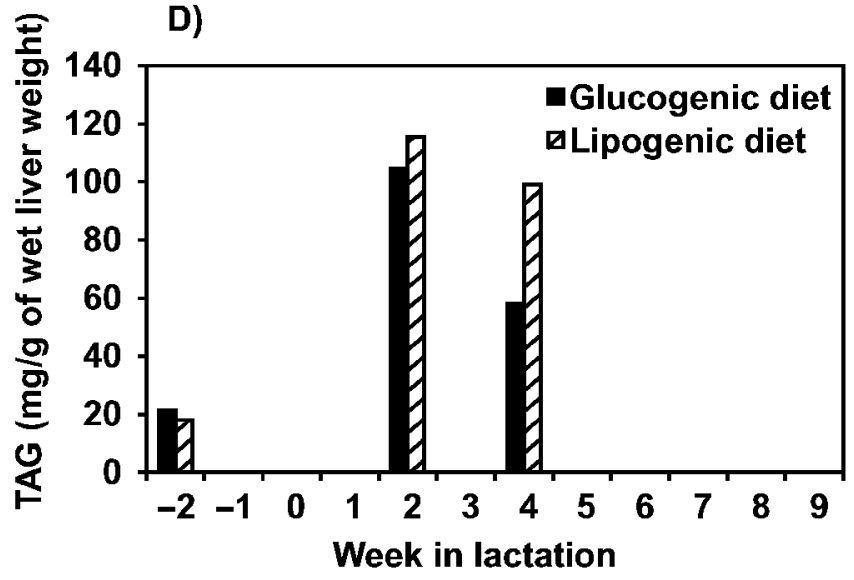

F)

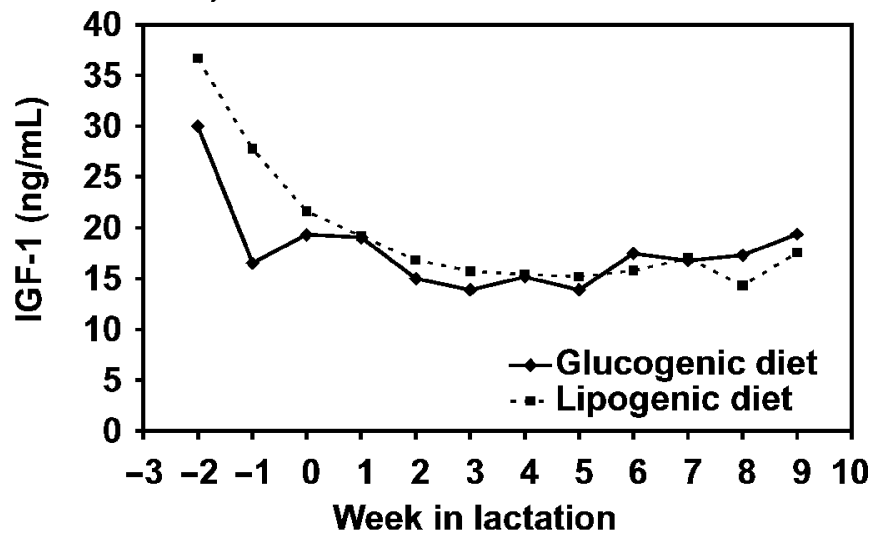

Figure 2. A) Plasma NEFA (mmol/L); B) plasma BHBA (mmol/L); C) plasma cholesterol (mmol/L); D) liver triacylglycerides (TAG, mg/ $\mathrm{g}$ of wet liver weight); E) plasma insulin $(\mu \mathrm{IU} / \mathrm{mL})$; and F) plasma IGF-I (ng/mL) from wk -2 to 9 postpartum for dairy cows fed a mainly glucogenic or lipogenic diet. Values represent least squares means per diet per week. Overall SEM: NEFA = 0.03; BHBA = 0.16; cholesterol = $0.25 ;$ TAG $=10.0 ;$ insulin $=0.07$ (natural logarithm); IGF-I $=1.45$.

when only the postpartum data were taken into account. Dietary effects on plasma insulin concentration were more pronounced postpartum, which can be explained by an increase in contribution of the experimental concentrates to the TMR postpartum. Insulin is known as a key regulator of nutrient repartitioning from body tissue to milk in the transition period from pregnancy to lactation (Laarveld et al., 1981). Low plasma insulin concentrations reduce glucose uptake by muscle and adipose tissue and facilitate increased uptake of glucose by the mammary gland, which is not insulin-responsive (Bauman and Elliot, 1983). A hyper- 
Table 2. Regression coefficients $(\beta)$ of NEFA and glucose related to plasma BHBA, triacylglyceride (TAG), insulin, milk fat, and milk fat production

\begin{tabular}{|c|c|c|c|c|c|c|}
\hline & $\begin{array}{l}\text { BHBA } \\
(\mathrm{mmol} / \mathrm{L})\end{array}$ & $\begin{array}{c}\text { TAG } \\
\text { (mg/g of wet } \\
\text { liver weight) }\end{array}$ & $\begin{array}{c}\text { NEFA } \\
(\mathrm{mmol} / \mathrm{L})\end{array}$ & Insulin ${ }^{1}$ & $\begin{array}{c}\text { Milk fat } \\
(\%)\end{array}$ & $\begin{array}{l}\text { Milk fat } \\
(\mathrm{kg} / \mathrm{d})\end{array}$ \\
\hline Glucose $(\mathrm{mmol} / \mathrm{L})$ & $-1.28^{\mathrm{a}}$ & $-29.3^{b}$ & -0.01 & $0.33^{\mathrm{a}}$ & $-0.38^{\mathrm{a}}$ & $-0.06^{\mathrm{b}}$ \\
\hline NEFA (mmol/L) & 0.30 & $131.0^{\mathrm{a}}$ & & $-0.82^{\mathrm{a}}$ & $0.90^{\mathrm{a}}$ & $0.14^{\mathrm{b}}$ \\
\hline
\end{tabular}

insulinemic-euglemic clamp in dairy cows in early lactation was shown to decrease milk yield and positively affect the EB (Butler et al., 2003). In the current study, the negative relationship $(P<0.05)$ between plasma NEFA and insulin and a tendency for a negative relationship between $\mathrm{ER}_{\mathrm{f}}$ and insulin confirm the importance of insulin status in relationship to the EB in dairy cows in early lactation. In addition, insulin has been suggested to restore hepatic growth hormone responsiveness in dairy cows in NEB (Butler et al., 2003). Although no diet effect or increase with week pp on plasma IGF-I concentration was found, it can be speculated that the diet effect on insulin concentration or the increase in insulin concentration with week pp for cows fed the glucogenic diet was not enough to restore growth hormone responsiveness during the first 9 wk of lactation.

Considering the lipogenic effect of insulin, the low insulin concentration in cows fed the lipogenic diet corresponds with a tendency for higher plasma NEFA concentration. An increase in NEFA concentrations for cows fed the lipogenic diet compared with the glucogenic diet corresponds with other studies that increased the dietary fat content and also found an increase in plasma NEFA concentration (e.g., Grum et al., 1996;

Table 3. Regression coefficients $(\beta)$ of energy retention in body mass $(\mathrm{ER})$, energy retention as body fat $\left(\mathrm{ER}_{\mathrm{f}}\right)$, energy retention as body protein $\left(\mathrm{ER}_{\mathrm{p}}\right)$ related to milk fat, fat to protein ratio, plasma glucose, NEFA, BHBA, liver triacylglyceride (TAG), plasma insulin, IGF-I, triiodothyronine (T3), and thyroxin (T4)

\begin{tabular}{|c|c|c|c|}
\hline Item & ER & $\mathrm{ER}_{\mathrm{f}}$ & $\mathrm{ER}_{\mathrm{p}}$ \\
\hline & & $\mathrm{kJ} / \mathrm{kg}^{0.75} / \mathrm{d}$ & \\
\hline Milk fat (\%) & $-374.2^{\mathrm{a}}$ & $-298.7^{\mathrm{a}}$ & $-73.1^{\mathrm{a}}$ \\
\hline Fat to protein ratio & -297.9 & -379.6 & 75.6 \\
\hline Glucose $(\mathrm{mmol} / \mathrm{L})$ & 0.5 & 1.1 & 2.3 \\
\hline $\mathrm{NEFA}(\mathrm{mmol} / \mathrm{L})$ & $-597.0^{\mathrm{a}}$ & $-515.5^{\mathrm{a}}$ & $-84.4^{\mathrm{c}}$ \\
\hline BHBA (mmol/L) & -49.8 & -43.6 & -7.3 \\
\hline Liver TAG (mg/g of wet weight) & -1.8 & -1.3 & -0.4 \\
\hline Insulin $^{1}$ & $109.3^{\mathrm{c}}$ & $99.3^{c}$ & 17.3 \\
\hline IGF-I (ng/mL) & -0.6 & -0.4 & -0.1 \\
\hline T3 (ng/mL) & 100.0 & 91.3 & 2.8 \\
\hline $\mathrm{T} 4(\mathrm{ng} / \mathrm{mL})$ & -11.7 & -8.8 & -3.4 \\
\hline
\end{tabular}

${ }^{\mathrm{a}} P<0.01 ;{ }^{\mathrm{c}} P<0.10$.

${ }^{1}$ Natural logarithm of plasma insulin concentration $(\mu \mathrm{IU} / \mathrm{mL})$.
Salado et al., 2004). However, these studies did not feed isocaloric diets, but increased the dietary energy content with the fat addition. Other studies released a decrease in DMI with dietary fat addition (Simas et al., 1995; Beam and Butler, 1998) without compromising milk production, which resulted in more BW loss. In the current study, the higher plasma NEFA concentration in the lipogenic diet group likely originated from the mobilized body fat reserves, as indicated by the relationship between $\mathrm{ER}_{\mathrm{f}}$ and plasma NEFA concentration.

Nonesterified fatty acids, originating from body fat stores, are mobilized to compensate for NEB and to be oxidized in the Krebs cycle and respiratory chain reaction to make energy available to the body (Webster, 1993). In the Krebs cycle, oxaloacetate, a C3 nutrient, plays a crucial role. However, during periods of relative excess of NEFA (e.g., during NEB), NEFA can follow several alternative pathways. First, dairy cows in early lactation exhibit incomplete oxidation of fatty acids as indicated by high concentrations of ketone bodies (Guretzky et al., 2006). The second alternative pathway for mobilized NEFA is incorporation of NEFA into milk fat, directly or indirectly via esterification to very low density lipoproteins (VLDL), which causes an increase in long-chain fatty acids in milk (Belyea and Adams, 1990). The third alternative for NEFA is esterification to TAG in the liver, possibly causing a fatty liver (Bobe et al., 2004). Fatty liver occurs when the rate of fatty acid esterification exceeds the rate of TAG disappearance via export from the liver as a component of VLDL. It has been suggested that hepatic secretion of TAG is positively correlated with the lipogenic capacity of the liver (Pullen et al., 1990). The predominant site for lipogenesis in ruminants is adipose tissue, which might explain the low rate of hepatic secretion of TAG in ruminants (Emery et al., 1992) compared with rat (Kleppe et al., 1988), chicken, and fish (Pullen et al., 1990). Consequently, this makes ruminants more susceptible to TAG accumulation in the liver during a period of NEB, eventually causing a fatty liver.

Plasma BHBA was high $(>2.0 \mathrm{mmol} / \mathrm{L})$ for cows in both dietary treatment groups from wk 1 to $8 \mathrm{pp}$ (Figure 
2). This suggests that this alternative pathway is used irrespective of dietary treatment in early lactation. In support, the nonsignificant regression coefficient of NEFA on BHBA suggests that NEFA concentrations do not determine the extent of incomplete oxidation and production of BHBA in periparturient dairy cows. In contrast, the regression coefficient of plasma glucose on BHBA was significant. This suggests that plasma glucose had a negative relationship with the plasma BHBA concentration. It has been reported that feeding cows glucogenic nutrients in early lactation decreases plasma BHBA and acetate concentrations (Pickett et al., 2003). Although we discussed the existence of a difference in fat availability from diet and mobilized body reserves between diets in the current study, the increase in lipogenic nutrients with the lipogenic diet did not result in an increase in plasma BHBA concentration as suggested earlier (Drackley, 1999; van Knegsel et al., 2005).

The second alternate pathway for NEFA seems to be used throughout the experimental period. A positive relationship was detected between plasma NEFA and milk fat yield. Body fat mobilization and NEFA were both higher in cows fed the lipogenic diet and simultaneously milk fat yield was increased by $220 \mathrm{~g} / \mathrm{cow}$ per day. Glucogenic nutrients lower milk fat percentage and often lower daily milk fat yield (e.g., Pickett et al., 2003).

With regard to the third alternative pathway, the current results do not support our hypothesis (van Knegsel et al., 2005) that a diet high in glucogenic nutrients decreases hepatic TAG accumulation. This might be caused by the fact that the dietary treatment was established by feeding concentrates differing in lipogenic and glucogenic nutrient content, whereas the contribution of concentrates to the diet increased from parturition until 3 wk pp. In wk $2 \mathrm{pp}$, liver TAG content was high, but not different between diets. In wk $4 \mathrm{pp}$ liver TAG was numerically lower in cows fed the glucogenic diet, but did not differ significantly from cows fed the lipogenic diet. This observation corresponds with the relative reduction in fat load in cows fed the glucogenic diet compared with cows fed the lipogenic diet as discussed above.

\section{CONCLUSIONS}

In conclusion, the results of this study suggest that plasma insulin is an intermediate in altering energy partitioning in dairy cows in early lactation. Feeding lactating dairy cows a diet high in glucogenic nutrients resulted in a less negative NEB due to anabolic effects of a high insulin concentration. The relative abundance of lipogenic nutrients, when feeding a more lipogenic diet, resulted in more excretion of lipogenic nutrients in milk and an increased recovery time from a NEB. Although it can be expected that cows with an improved EB suffer less from hepatic TAG accumulation and elevated plasma ketone concentrations the current experiment could not confirm this hypothesis.

\section{ACKNOWLEDGMENTS}

The authors thank the Product Board Animal Feed (PDV) and Dutch Dairy Board (PZ) for the financial support of this experiment. The authors thank staff of the experimental facility 'De Haar' for technical assistance and Marleen Scheer for the liver biopsies.

\section{REFERENCES}

Adler, J. H. 1970. Theoretical quantitative approach to the mechanism of hypoglycemic ketosis in ruminants. J. Theor. Biol. 28:101-109.

Bauman, D. E., and J. M. Elliot. 1983. Control of nutrient partitioning in lactating ruminants. Pages $437-468$ in Biochemistry of Lactation. T. B. Mepham, ed. Elsevier, Amsterdam, the Netherlands.

Beam, S. W., and W. R. Butler. 1998. Energy balance, metabolic hormones, and early postpartum follicular development in dairy cows fed prilled lipid. J. Dairy Sci. 81:121-131.

Belyea, R. L., and M. W. Adams. 1990. Energy and nitrogen utilization of high versus low producing dairy cows. J. Dairy Sci. 73:10231030 .

Bobe, G., J. W. Young, and D. C. Beitz. 2004. Invited review: Pathology, etiology, prevention, and treatment of fatty liver in dairy cows. J. Dairy Sci. 87:3105-3124.

Bouchard, G., D. Johnson, T. Carver, B. Paigen, and M. C. Carey. 2002. Cholesterol gallstone formation in overweight mice establishes that obesity per se is not linked directly to cholelithiasis risk. J. Lipid Res. 43:1105-1113.

Butler, S. T., A. L. Marr, S. H. Pelton, M. C. Lucy, and W. R. Butler. 2003. Insulin restores GH responsiveness during lactation-induced negative energy balance in dairy cattle: Effects on expression of IGF-I and GH receptor 1A. J. Endocrinol. 176:205-217.

De Vries, M. J., and R. F. Veerkamp. 2000. Energy balance of dairy cattle in relation to milk production variables and fertility. J. Dairy Sci. 83:62-69.

Drackley, J. K. 1999. ADSA Foundation Scholar Award. Biology of dairy cows during the transition period: The final frontier? J. Dairy Sci. 82:2259-2273.

Emery, R. S., J. S. Liesman, and T. H. Herdt. 1992. Metabolism of long chain fatty acids by ruminant liver. J. Nutr. 122:832-837.

Gerrits, W. J. J., E. Decuypere, M. W. A. Verstegen, and V. Karabinas. 1998. Effect of protein-free energy intake on plasma concentrations of insulin-like growth factor I and thyroid hormones in preruminant veal calves. J. Anim. Sci. 76:1356-1363.

Grum, D. E., J. K. Drackley, L. R. Hansen, and J. D. Cremin. 1996. Production, digestion, and hepatic lipid metabolism of dairy cows fed increased energy from fat or concentrate. J. Dairy Sci. 79:1836-1849.

Grummer, R. R. 1993. Etiology of lipid-related metabolic disorders in periparturient dairy cows. J. Dairy Sci. 76:3882-3896.

Guretzky, N. A., D. B. Carlson, J. E. Garrett, and J. K. Drackley. 2006. Lipid metabolite profiles and milk production for Holstein and Jersey cows fed rumen-protected choline during the periparturient period. J. Dairy Sci. 89:188-200.

Kleppe, B. B., R. J. Aiello, R. R. Grummer, and L. E. Armentano. 1988. Triglyceride accumulation and very low density lipoprotein secretion by rat and goat hepatocytes in vitro. J. Dairy Sci. 71:1813-1822. 
Kokkonen, T., J. Taponen, T. Anttila, L. Syrjala-Qvist, C. Delavaud, Y. Chilliard, M. Tuori, and A. T. Tesfa. 2005. Effect of body fatness and glucogenic supplement on lipid and protein mobilization and plasma leptin in dairy cows. J. Dairy Sci. 88:1127-1141.

Kronfeld, D. S. 1976. Bovine ketosis in high yielding dairy cows. The potential importance of the proportions of glucogenic, lipogenic and aminogenic nutrients in regard to the health and productivity of dairy cows. Fortschr. Tierphysiol. Tierernahr. 7:3-26.

Laarveld, B., D. A. Christensen, and R. P. Brockman. 1981. The effect of insulin on net metabolism of glucose and amino acids by the bovine mammary gland. Endocrinology 108:2217-2221.

Littell, R. C., G. A. Milliken, W. W. Stroup, R. D. Wolfinger, and S. O. 2006. SAS ${ }^{\circledR}$ for Mixed Models. 2nd ed. SAS Institute Inc., Cary, NC.

National Research Council. 2001. Nutrient Requirements of Dairy Cattle. 7th rev. ed. Natl. Acad. Sci., Washington, DC.

Owens, F. N., D. S. Secrist, W. J. Hill, and D. R. Gill. 1998. Acidosis in cattle: A review. J. Anim. Sci. 76:275-286.

Palmquist, D. L., and W. Mattos. 1978. Turnover of lipoproteins and transfer to milk fat of dietary (1-carbon-14) linoleic acid in lactating cows. J. Dairy Sci. 61:561-565.

Pickett, M. M., M. S. Piepenbrink, and T. R. Overton. 2003. Effects of propylene glycol or fat drench on plasma metabolites, liver composition, and production of dairy cows during the periparturient period. J. Dairy Sci. 86:2113-2121.

Pullen, D. L., J. S. Liesman, and R. S. Emery. 1990. A species comparison of liver slice synthesis and secretion of triacylglycerol from nonesterified fatty acids in media. J. Anim. Sci. 68:1395-1399.

Rukkwamsuk, T., T. A. Kruip, G. A. Meijer, and T. Wensing. 1999 Hepatic fatty acid composition in periparturient dairy cows with fatty liver induced by intake of a high energy diet in the dry period. J. Dairy Sci. 82:280-287.

Rukkwamsuk, T., T. Wensing, and M. J. Geelen. 1998. Effect of overfeeding during the dry period on regulation of adipose tissue metabolism in dairy cows during the periparturiant period. J. Dairy Sci. 81:2904-2911.
Salado, E. E., G. A. Gagliostro, D. Becu-Villalobos, and I. LacauMengido. 2004. Partial replacement of corn grain by hydrogenated oil in grazing dairy cows in early lactation. J. Dairy Sci. $87: 1265-1278$.

Simas, J. M., J. T. Huber, Z. Wu, K. H. Chen, S. C. Chan, C. B. Theurer, and R. S. Swingle. 1995. Influence of steam-flaked sorghum grain and supplemental fat on performance of dairy cows in early lactation. J. Dairy Sci. 78:1526-1533.

Tamminga, S., P. A. Luteijn, and R. G. M. Meijer. 1997. Changes in composition and energy content of live weight loss in dairy cows with time after parturition. Livest. Prod. Sci. 52:31-38.

Tamminga, S., W. M. Van Straalen, A. P. J. Subnel, R. G. M. Meijer, A. Steg, C. J. G. Wever, and M. C. Blok. 1994. The Dutch protein evaluation system: The DVE/OEB-system. Livest. Prod. Sci. 40:139-155.

Van den Top, A. M., T. Wensing, M. J. Geelen, G. H. Wentink, A. T. Van’t Klooster, and A. C. Beynen. 1995. Time trends of plasma lipids and enzymes synthesizing hepatic triacylglycerol during postpartum development of fatty liver in dairy cows. J. Dairy Sci. 78:2208-2220

van Knegsel, A. T. M., H. van den Brand, J. Dijkstra, W. M. Van Straalen, M. J. W. Heetkamp, S. Tamminga, and B. Kemp. 2007. Dietary energy source in dairy cows in early lactation: Energy partitioning and milk composition. J. Dairy Sci. 90:1467-1476.

van Knegsel, A. T. M., H. Van den Brand, J. Dijkstra, S. Tamminga, and B. Kemp. 2005. Effect of dietary energy source on energy balance, production, metabolic disorders and reproduction in lactating dairy cattle. Reprod. Nutr. Dev. 45:665-688.

Verstegen, M. W. A., W. Van der Hel, H. A. Brandsma, A. M. Henken, and A. M. Bransen. 1987. The Wageningen respiration unit for animal production research: A description of the equipment and its possibilities. Pages 21-48 in Energy Metabolism in Farm Animals: Effects of Housing, Stress and Disease. M. W. A. Verstegen and A. M. Henken, ed. Martinus Nijhoff Publishers, Dordrecht, the Netherlands.

Webster, J. 1993. Understanding the Dairy Cow. Blackwell Publishing, Oxford, UK. 